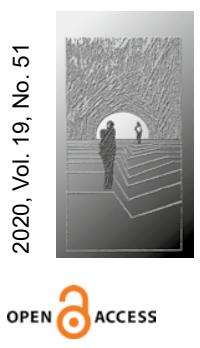

Anna Dębicka

http://orcid.org/0000-0001-9885-0799

Poznan University of Technology

Faculty of Engineering Management

Chair of Entrepreneurship and Business Communication anna.debicka@put.poznan.pl

Karolina Olejniczak

http://orcid.org/0000-0003-3563-8015

Poznan University of Technology

Faculty of Engineering Management

Chair of Entrepreneurship and Business Communication

karolina.olejniczak@put.poznan.pl

DOI: 10.35765/hw.1892

\title{
Entrepreneurial Pedagogy: An Example of Using Student-Developed Case Studies
}

\begin{abstract}
RESEARCH OBJECTIVE: The article attempts to explain the benefits that may result from the use of case studies developed by students as a teaching method applied in entrepreneurial pedagogy.
\end{abstract}

THE RESEARCH PROBLEM AND METHODS: The main research problem concerns the effectiveness of using case studies created by students as a teaching method in entrepreneurial pedagogy. The article provides an overview of selected literature and presents the authors' experience in applying student-developed case studies.

THE PROCESS OF ARGUMENTATION: In the first part of the article, the most important entrepreneurial skills and competences are discussed. Subsequently, the importance of using activating methods is presented, with particular emphasis on the case study. In the second part, the use of the case study developed by students was analyzed and evaluated. Finally, the conclusions and recommendations are presented.

RESEARCH RESULTS: The literature analysis indicates the importance of methods that foster students' active involvement, including case studies, in entrepreneurial pedagogy. The analysis of case studies developed by students showed their strong commitment to the assignment. Students had to gain knowledge of the operation of enterprises and the processes that take place in them. In addition, the task required students to be familiar with methods and tools that support creative thinking and problem-solving skills.

CONCLUSIONS, INNOVATIONS, AND RECOMMENDATIONS: Based on the analysis of literature and student-developed case studies, it seems that the discussed method is an effective teaching method that increases students' commitment to the assignment and supports the development of entrepreneurial attitudes and skills. Furthermore, this method provides a range of benefits that give the teacher great freedom in choosing the issues and scope of case studies created by students.

Suggested citation: Dębicka, A. i Olejniczak, K. (2020). Entrepreneurial Pedagogy: An Example of Using Student-Developed Case Studies. Horyzonty Wychowania, 19(51), 43-55. DOI: 10.35765/hw.1892. 


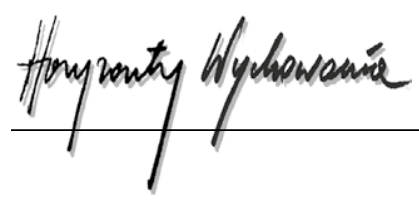

The results of the analysis permit concluding that student-developed case studies can be commonly used and allow developing a wide range of students entrepreneurial skills.

\section{$\rightarrow$ KEYWORDS: ENTREPRENEURIAL PEDAGOGY, CASE STUDY, PROBLEM} SOLVING, ENTREPRENEURIAL SKILLS

\section{Introduction}

The importance of entrepreneurship education, which aims to stimulate entrepreneurial activity through the development of key entrepreneurial competences, is emphasized by many authors and state institutions around the world (Ismail, Zain, \& Zulihar, 2015; Karimi, Biemans, Lans, Chizari, \& Mulder, 2016; Nabi, Liñán, Fayolle, Krueger, \& Walmsley, 2017). Since 2003, the European Commission has confirmed, through its numerous studies and reports, the importance of developing entrepreneurial competences for a knowledge-based society (Bacigalupo, Kampylis, Punie, \& Van den Brande, 2016, pp. 5-6). It therefore seems that, along with the dynamically changing economy, the approach to entrepreneurship education must change (Ratten \& Usmanij, 2020), in terms of developing both relevant competences and skills and the teaching methods used. Skills such as creative thinking, flexibility, design thinking, which are more difficult to develop using traditional teaching methods, are becoming increasingly important (Kickul, Gundry, Mitra, \& Berçot, 2018). Entrepreneurship education can be seen in various dimensions. The approach to entrepreneurship education in this article refers to the broader concept of education through entrepreneurship, where education is not necessarily focused on entrepreneurship but more on pedagogy and teaching methods (Moberg, 2014).

The purpose of this article is to present, analyze and evaluate the experience resulting from the use of the student-developed case study method. The uniqueness of the conducted research results from the analysis of experimental variation of the case study method, which is not yet widely used and may be an interesting alternative. The presented research initially assumed that a case study which is created by students can increase their involvement in the task and effectively develop entrepreneurial competences and attitudes. Although the study is based on a detailed description of the method chosen and the results obtained, which allow drawing basic conclusions, there is a danger of being subjective. In order to limit the subjective assessment, the authors tried to confront their experience with the experience of other researchers of this problem.

The study is divided into three main parts. In the first one, theoretical background in the field of entrepreneurial competences and methods used in entrepreneurial pedagogy is discussed. In the second part, a detailed description of the course using the studentdeveloped case study method is presented. The article ends with conclusions that can be helpful to practitioners and scholars who use alternative teaching methods, indicating both the benefits and limitations of using the chosen method. 


\section{Entrepreneurial Competences, Skills and Attitudes}

The perception of competences, skills and attitudes is often defined and interpreted in a variety of ways. Competences and skills are frequently treated equally and are called alternately, which may hinder the differentiation between them. According to Lathi (1999), competences are a compilation of elements such as knowledge, skills and behavior or attitudes that are needed to perform specific functions. The OECD (2015) emphasizes similar observations, indicating that competences should be considered in a much broader context, given the demanding environment that forces individuals to face the complex challenges of the contemporary world. Competence in the context of the EntreComp study is understood as a set of knowledge, skills and attitudes, while skills can be defined as the ability to apply knowledge and use know-how to complete tasks and solve various problems (Bacigalupo et al., 2016, pp. 20-21; European Parliament and the Council, 2008/C 111/01). Entrepreneurial skills may refer to market orientation/market awareness, creativity, flexibility, leadership, problem solving, and collaboration/teamwork (Driessen \& Zwart, 2002; Hodzic, 2016; Ismail et al., 2015; Leon, 2017).

The approach presented, among others, by Oosterbeek, van Praag and IJsselstein (2010) defines entrepreneurial competences in two key areas: entrepreneurial characteristics and skills (also referred to as managerial competence). The most important elements of the characteristics are: (1) need of achievement; (2) need of autonomy; (3) need of power; (4) social orientation; (5) self-efficacy; (6) endurance; and (7) risktaking propensity. In turn, the most frequently mentioned skills include: (1) market awareness; (2) creativity (innovativeness) and (3) flexibility. Skills can also include those that are directly related to business knowledge, such as finance, marketing, sales, and accounting. (Driessen \& Zwart, 2002; Ismail et al., 2015).

In the literature, apart from competences and skills, entrepreneurial attitudes and intentions are also defined and analyzed. Entrepreneurial intentions may depend on entrepreneurial motivation and entrepreneurship education (Küttim, Kallaste, Venesaar, \& Kiis, 2014; Li, Wu, \& Wu, 2008). However, not all studies confirm these relationships. It happens that entrepreneurship education programs do not achieve the expected results. For example, research by Barba-Sánchez and Atienza-Sahuquillo (2018) indicates that entrepreneurship education may not have a significant impact on entrepreneurial intentions. Nevertheless, the results obtained, as suggested by the authors, may depend on the teaching methods, environment and approach to entrepreneurship education (BarbaSánchez \& Atienza-Sahuquillo, 2018, p. 58). Similarly, research conducted by Oosterbeekć et al. (2010) in the Netherlands showed no significant impact of the selected entrepreneurship education program on the entrepreneurial competences of the surveyed students. Such a result, according to the authors, may be caused by acquiring knowledge that presents the true aspects of conducting own business, and this, as a consequence, may lead to a reduction of student enthusiasm and their initial "optimism."

It seems that entrepreneurship education can enhance entrepreneurial competences and intentions among students; nevertheless, it depends on many factors, including 


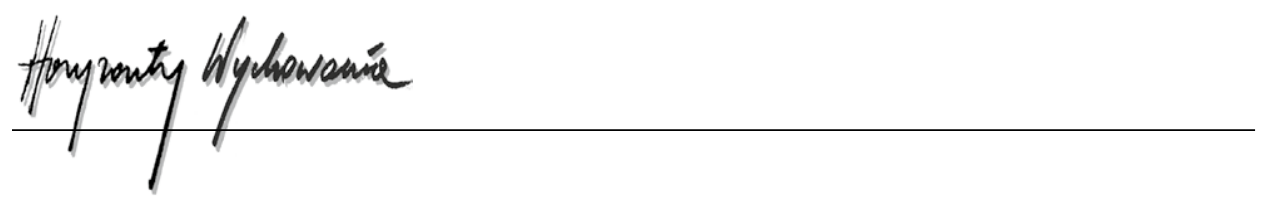

the implementation of entrepreneurial pedagogy (Carrier, 2007; Kearney, 1999; Wach, 2014).

\section{The Importance of Teaching Methods in Relation to Entrepreneurial Skills}

Strengthening entrepreneurial intentions and competences is a big challenge for current education. In many studies, it is entrepreneurship education that is the key element responsible for the development of entrepreneurial skills and attitudes (Fayolle, Verzat, \& Wapshott, 2016, p. 897; Pittaway \& Cope, 2016). As indicated in the studies of Ismail, Zain and Zulihar (2015), elements of entrepreneurial skills such as creativity and flexibility must be supported by appropriate teaching methods. It is entrepreneurial pedagogy that deals with teaching methods that promote entrepreneurial attitudes and skills among students (Wach, 2014, p. 13).

One of the main conclusions presented in the final report of the European Commission indicated that entrepreneurship is best taught by methods that include learning in real-life conditions. In addition, students benefit most from simulations and tasks that require specific problem solving (Davies, 2002; European Commission, 2015, pp. 89-90; Häkkinen et al., 2017). This is also confirmed by Wach (2014), who points out that the most important entrepreneurial teaching methods encompass problem-solving methods, including creative thinking and learning by discovery, i.e. such methods that foster students' active involvement in general. Research conducted by Lumpkin, Hills and Shrader (2004) similarly indicates how important, from the perspective of entrepreneurship, is teaching creativity skills that can have a positive impact on enhancing opportunity identification competences. In addition, the authors point out that the case-based approach should be used in entrepreneurship education, while underlining that teaching activities should also enable students to be more creative.

The case study method, referring to research conducted by Leon (2016), is one of the most popular teaching methods, right after the lecture used by higher education institutions in the European Union member states. However, the student-developed case study method is an experimental approach that is not yet widely used. Nevertheless, it has been successfully employed, among others, to teach ethics in management, marketing and in other areas (Epps, 2008; Laditka \& Houck, 2006; Ross \& Wright, 2000). For example, Laditka and Houck (2006) describe their experience with the application of the method discussed, pointing out that this approach seems to be an effective way to actively engage students in reflecting on selected issues. The authors also point out that this type of assignment can be applied in a variety of business courses, including strategy, leadership or decision making. 


\section{The Research Method and Results}

The purpose of this study was to analyze and evaluate experiences resulting from the use of an experimental teaching method in which students are responsible for creating their own case study. The starting point of the presented research was the assumption that a case study which students create themselves can increase their commitment to the task and effectively develop entrepreneurial competences among which, next to business knowledge, creativity and problem-solving skills are equally important. In addition, from the perspective of entrepreneurial pedagogy, this method may allow students to learn through experience and mobilizes them for collaborative work.

The group that carried out the assignment of creating their own case study consisted of 25 students of first cycle full-time studies in the field of logistics. Our article reports on the experience of using this assignment for one semester. The classes lasted 15 hours, which included an introductory lecture, group sessions and a final presentation session (Table 1).

Table 1

Description of the student-developed case study method tested

\begin{tabular}{|c|c|}
\hline Topic of case study: & The problems does not concern us (does it?) \\
\hline Length: & $\begin{array}{l}15 \text { hours (an introductory lecture, group sessions and a final } \\
\text { presentation session) }\end{array}$ \\
\hline Level: & 1st year (bachelor level) - logistics \\
\hline Student count for the course: & 25 \\
\hline Group size: & 3 \\
\hline Aim: & $\begin{array}{l}\text { The goal of the task can be presented at two levels. The first one was } \\
\text { to strengthen students' involvement in the course program by their } \\
\text { creating their own case study. } \\
\text { The second level resulted from the assumptions of the course } \\
\text { among which the most important are: encourage students to think } \\
\text { creatively, encourage students to search for additional knowledge } \\
\text { in the field of enterprise functioning, with particular emphasis on } \\
\text { processes occurring in a given enterprise and problems that may be } \\
\text { encountered, acquire problem-solving skills. }\end{array}$ \\
\hline Key skills: & Group work, creativity, problem solving, presentational skills. \\
\hline Assessment: & Group presentation and discussion \\
\hline
\end{tabular}

Source: own study.

The sex distribution in the studied group was relatively even, with a slight predominance of males (56\%), as shown in Table 2. The base group was divided into 9 smaller teams. The median group size was 3 . 


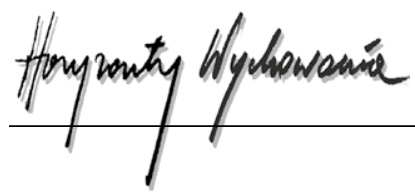

Table 2

Number and percentage of male and female participants

\begin{tabular}{lcr} 
& \multicolumn{2}{l}{ Participants $\mathrm{N}=25$} \\
\cline { 2 - 3 } & \multicolumn{1}{c}{$\mathrm{N}$} & $\%$ \\
\cline { 2 - 3 } & & \\
Male & 14 & 56 \\
Female & 11 & 44 \\
Total & 25 & 100
\end{tabular}

Source: own study.

The evaluation of the obtained results comes down to the authors' assessment in two dimensions. The first refers to the description of classes using the chosen method. The second refers to the assessment of case studies developed by students, with particular emphasis on acquired skills - for this purpose, the presented evaluation sheet was used (Figure 1).

\begin{tabular}{|c|c|c|c|c|c|}
\hline Case Study & $\begin{array}{c}\text { Needs } \\
\text { improvement }\end{array}$ & \multicolumn{3}{|c|}{ Meets expectations } & $\begin{array}{c}\text { Exceeds } \\
\text { expectations }\end{array}$ \\
\hline \multirow{2}{*}{$\begin{array}{c}\text { Overall assessment of the case study created: } \\
\text { Structure } \\
\text { Logical, Inclusive, Thorough } \\
\text { Involvement }\end{array}$} & 1 & 2 & 3 & 4 & 5 \\
\hline & $\square$ & $\square$ & L & $\square$ & $\square$ \\
\hline \multirow{2}{*}{$\begin{array}{l}\text { Definition of the problem: } \\
\text { Establishes problem significance } \\
\text { Clear statement of the problem }\end{array}$} & 1 & 2 & 3 & 4 & 5 \\
\hline & $\square$ & $\square$ & $\square$ & $\square$ & $\square$ \\
\hline \multirow{2}{*}{$\begin{array}{c}\text { Conclusions } \\
\text { Provided solution }\end{array}$} & 1 & 2 & 3 & 4 & 5 \\
\hline & $\square$ & $\square$ & $\square$ & $\square$ & $\square$ \\
\hline Skills & $\begin{array}{c}\text { Needs } \\
\text { improvement }\end{array}$ & \multicolumn{3}{|c|}{ Meets expectations } & $\begin{array}{c}\text { Exceeds } \\
\text { expectations }\end{array}$ \\
\hline \multirow{2}{*}{$\begin{array}{c}\text { Creativity Skills: } \\
\text { Can use at least one creative tool } \\
\text { A creative approach to the case study creation } \\
\text { process }\end{array}$} & 1 & 2 & 3 & 4 & 5 \\
\hline & $\square$ & $\square$ & $\square$ & $\square$ & $\square$ \\
\hline \multirow{2}{*}{$\begin{array}{l}\text { Problem-Solving Skills: } \\
\text { Identifies the problem and an optimal solution } \\
\text { Can use at least one tool of RCA }\end{array}$} & 1 & 2 & 3 & 4 & 5 \\
\hline & $\square$ & $\square$ & $\square$ & $\square$ & $\square$ \\
\hline \multirow{2}{*}{ Presentation Skills } & 1 & 2 & 3 & 4 & 5 \\
\hline & $\square$ & $\square$ & $\square$ & $\square$ & $\square$ \\
\hline Summary Comments & & & & & \\
\hline
\end{tabular}

Figure 1. Evaluation sheet.

Source: own study.

The classes started with a theoretical introduction in which information about the case study method and selected methods used in root cause analysis (RCA) was presented. Among the RCA methods, the following were discussed: 1) Cause and Effect Diagram 
(CED), 2) 5 WHYs, 3) mind mapping, 4) Pareto chart. Each method was exemplified. The most important guidelines were presented to students, which included information on both the subject of the case study and its structure.

The students' assignment was to create their own case study based on preliminary guidelines. The object of the case study was a selected enterprise or an enterprise that was created by students. By way of introduction and in order to strengthen commitment to the assignment, students were asked to briefly describe the chosen enterprise, which included a description of the business, presentation of the goals of the business, as well as short characteristics of competition. Next, the students were asked to present the production process of the chosen enterprise. They could choose any form of the process presentation. This part required the students to learn about the characteristics of the various stages of production at the same time mobilizing them to search for additional information by means of e.g. a review of websites, scientific articles or direct interviews with enterprises. In the next part of the assignment, the students were to present problems that appeared at the selected stages of production or problems that might occur in the future. The students presented the causes and effects of the most important problem using the CED method.

The analysis of case studies carried out in groups was discussed during classes by each group and discussed in the forum. The last stage consisted of conclusions that students had to submit from case studies presented by themselves and their colleagues during the presentation session. The students were asked to present what problems the company may encounter and how it may try to reduce the possibility of their occurrence. After this stage, the student work evaluation was carried out (Figure 2).

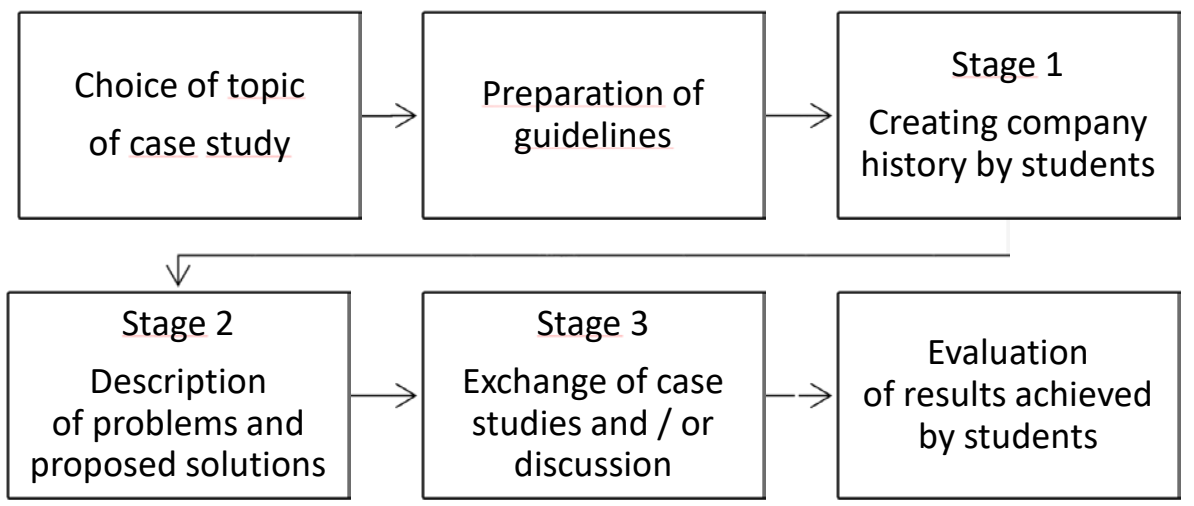

Figure 2. Student-developed case study process.

Source: own study. 


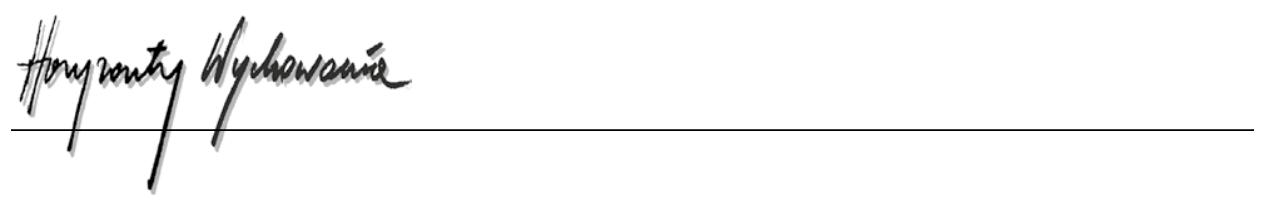

Several aspects were used to evaluate the effectiveness of the student-developed case studies, according to the presented evaluation sheet. The authors reviewed the content of each of the nine case studies presented and described the students' attitude to their assignment. First, the review of the presented case studies was done independently, then the overall evaluation was carried out in collaboration.

The first case study evaluation criterion that included "overall assessment of case study created" was assessed at a lower level compared to further assessed criteria. Most groups (5 out of 9 ) were rated at an average level of meeting expectations (Figure 3 ). The students found the most problems in constructing the case study in an orderly and logical manner. The vast majority of the groups presented the case study in a form reminiscent of a project rather than a case report. This may be due to students' previous experience in implementing projects. However, what positively surprised the authors is the involvement of groups in creating the image of the selected enterprise. At this point, it should be noted that all case studies presented described the enterprises created by the students that were mostly similar to enterprises they knew from their environment $(68 \%)$. The students showed particular creativity in creating the company description, including elements that were not required, such as logo design (4 out of 9 groups presented), vision and mission creation (all groups). The company's goals created by students well reflected the economic reality (referring, among others, to ecology and business responsibility).

The next evaluated element concerned the definition of the problem. All groups met the expectations. All the problems were presented in a legible manner, along with their significance for the company's operations. At this stage, in parallel to the defined problem, acquired knowledge of processes occurring in the selected enterprise was considered. All groups presented the production process using a block diagram. The presented problems were associated with the specificity of selected enterprises.

Further, the proposed solutions and the students' conclusions were evaluated. At this stage, we paid special attention to the problem analysis and the course of the discussion. The students were involved in this stage of the assignment. The discussion was substantive. The students actively participated in it, their observations were often accurate. Four of the nine groups at this stage were rated at the highest level "exceeds expectations." 


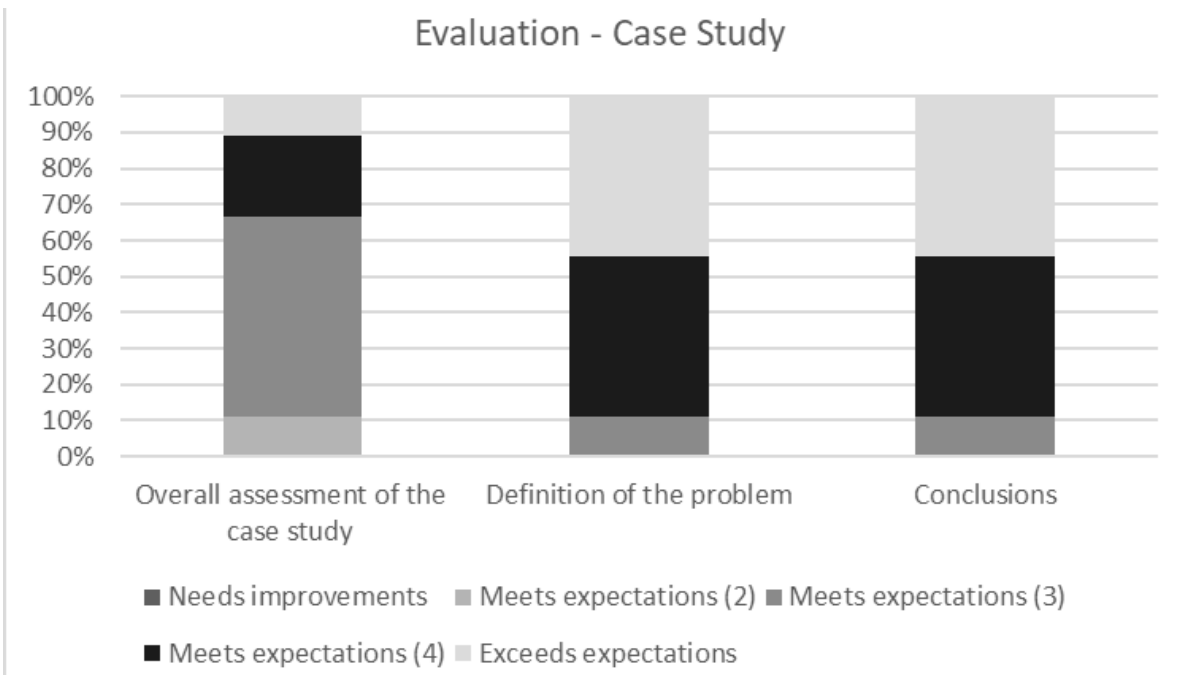

Figure 3. Evaluation - case study.

Source: own study.

This stage also allowed for further assessment of the students in relation to the development of their creativity, problem-solving, presentation skills (Figure 4).

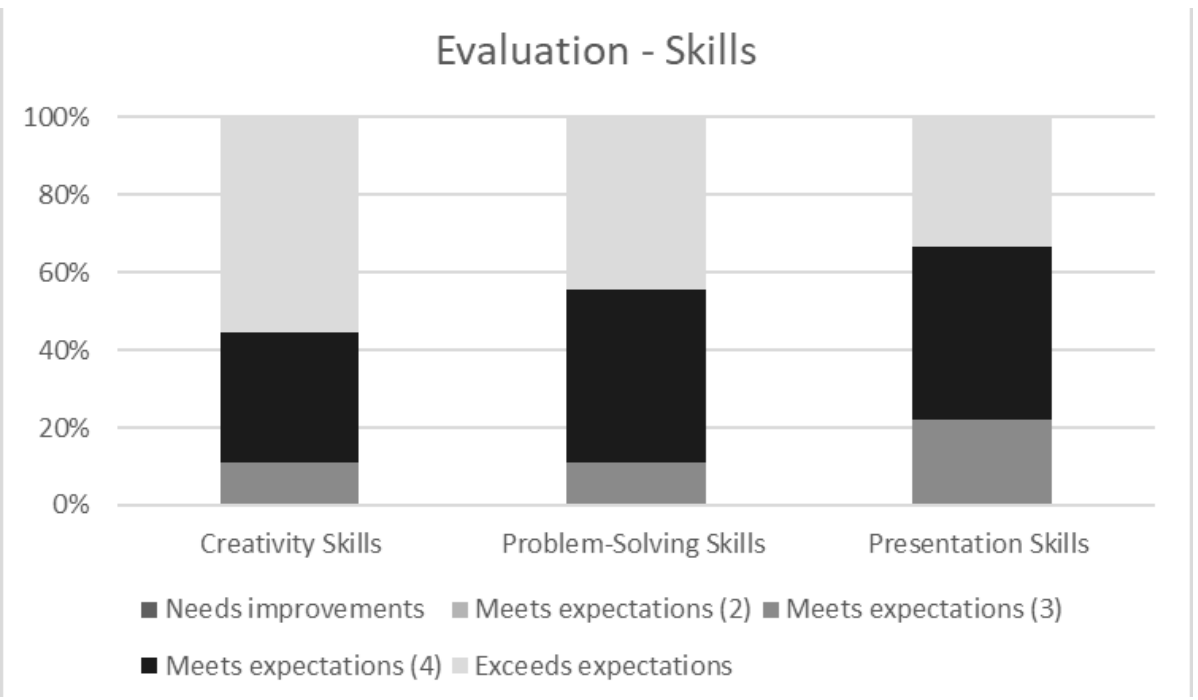

Figure 4. Evaluation - skills.

Source: own study. 


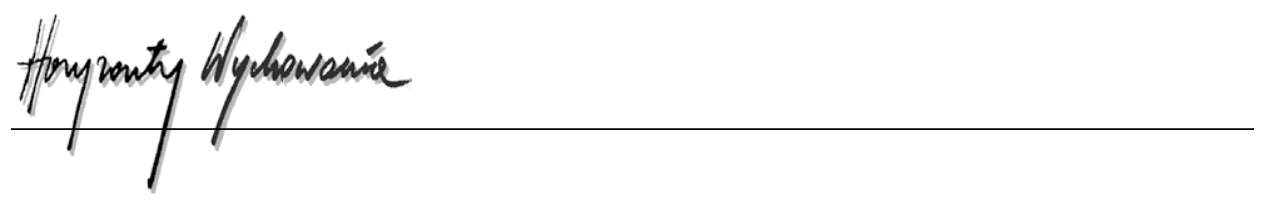

In relation to creativity and problem-solving skills, first of all, the ability to use RCA tools was assessed. All groups used the CED method in order to look for solutions to the presented problem. The average number of proposals presented in the CED was 52 (median 43). It is worth noting that 2 out of the 9 groups decided to use the 5 WHYs method additionally. The results obtained by these two groups differ significantly from the others. First, they indicated the most suggestions as to causes (exactly 113 and 68 with a median of 43 for all groups). In addition, these groups took advantage of six major root causes. When assessing creativity, the students' initiatives discussed earlier in creating the image of the selected enterprise were also taken into account. The acquired creativity and problem-solving skills were highly valued, 8 groups achieved a grade above the average.

\section{Conclusions}

Entrepreneurial pedagogy focuses on the application of innovative approaches and strategies to teaching that can positively influence the development of entrepreneurial competences and attitudes among students. Among the many entrepreneurial teaching methods mentioned, the case study method is still one of the most frequently used.

The main assumption of the tested method is to transfer responsibility for creating a case study to students. The principles of creation, scope and subject depend on the teacher who is responsible for creating guidelines for students. That is why this tool seems to be very versatile. Thanks to the teacher's freedom in choosing the subject of the case study and its level of difficulty, this method can be used at various levels of education and in different scientific fields.

It is worth paying attention to the disadvantages of using the traditional case study method presented in the literature, such as low student involvement in idea development, analyzing cases that often show the situation of companies operating in a different environment than those known to students and a lack of opportunities to develop negotiating and leadership skills (Gawel, 2012; Lynch, Kamovich, Longva, \& Steinert, 2019; Rasmussen \& Sørheim, 2006). Referring to the results of the research, some of these disadvantages can be reduced by involving students in the process of creating a case study.

First of all, the responsibility for creating a case study falls on the students, which in turn not only allows them to get involved in the creative process but also forces them to search for additional information. Through the implementation of their own case study, the students had to obtain information about production processes implemented in an enterprise. These processes were selected by comparing processes in companies with the same profile of activity, often by obtaining information from companies operating in their environment. Depending on the subject of the case study, students usually need to look for information to create their story in the economic environment they know. This gives additional benefits related to the broadening of knowledge not only about the examined company but also about the environment in which it operates. 
Secondly, as the research shows, the presented method contributed to the development of creativity skills. All study groups decided to create their own company, so each group came up with the name of their company. Among the case studies developed, 4 out of 9 groups presented (on their own initiative) company logos that they had created themselves (in a graphic form) for the needs of the case study, which may indicate high involvement of these groups in creating their own company history. Additionally, the presented case studies empowered the students to create the mission, vision and goals of the company, which, especially at the stage of presenting the final results, gave the impression that the groups identified with the analyzed companies.

Finally, the study shows that most groups demonstrated the ability to solve problems using selected methods. In addition, the students were very involved in the discussions and their observations were often accurate. Moreover, the problems presented by the groups allowed the students to better understand the issues associated with the emergence of problem situations in enterprises, especially in relation to the diversity of areas in which such situations may arise.

The experience of using the chosen method points also to some limitations:

First, students need a lot of time to be able to fully develop their case study. The best results can be obtained by using the experience of other companies, which requires time to look for an appropriate company and obtain enough data needed to create a case study.

Secondly, obtaining certain information from enterprises can be difficult, and using them non-anonymously may, according to some companies, pose a threat to them, especially if the data relates to their technology or sensitive information. This is probably why the analyzed case studies presented fictitious companies that were created in line with the model of existing companies from the students' environment.

Nevertheless, the described method seems to be an interesting solution and, according to the authors, requires further research, especially in the area of assessing the effects of its application in the context of developing entrepreneurial competences among students.

\section{BIBLIOGRAPHY}

Bacigalupo, M., Kampylis, P., Punie, Y., \& Van den Brande, G. (2016). EntreComp: The entrepreneurship competence framework.

Barba-Sánchez, V., \& Atienza-Sahuquillo, C. (2018). Entrepreneurial intention among engineering students: The role of entrepreneurship education. European Research on Management and Business Economics, 24(1), 53-61. https://doi.org/10.1016/j.iedeen.2017.04.001.

Carrier, C. (2007). Strategies for teaching entrepreneurship: What else beyond lectures, case studies and business plans? In Handbook of research in entrepreneurship education, Vol. 1. A general perspective, 143-159.

Davies, C.H.J. (2002). Student engagement with simulations: A case study. Computers \& Education, 39(3), 271-282. 


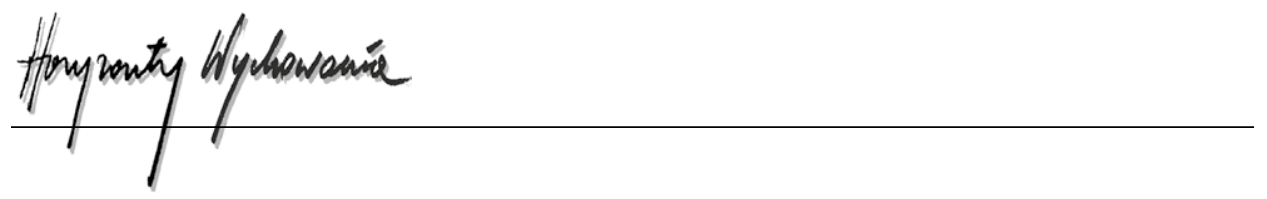

Driessen, M.P., \& Zwart, P.S. (2002). The role of the entrepreneur in small business success: The entrepreneurship scan. Retrieved from: https://pdfs.semanticscholar.org/480a/0039bcd325f9 9bb204f70d1ef92b046f0c1b.pdf.

Epps, A. (2008). Baby you can drive my car. Using primary target customers to develop your marketing communications. University of Wollongong in Dubai Working Paper Series.

European Commission. (2015). Entrepreneurship education: A road to success: A compilation of evidence on the impact of entrepreneurship education strategies and measures. Retrieved from: https://ec.europa.eu/growth/content/entrepreneurship-education-road-success-0_en

European Parliament and the Council. (2008). Recommendation of the European Parliament and of the Council of 23 April 2008 on the establishment of the European Qualifications Framework for lifelong learning (2008/C 111/01).

Fayolle, A., Verzat, C., \& Wapshott, R. (2016). In quest of legitimacy: The theoretical and methodological foundations of entrepreneurship education research. International Small Business Journal: Researching Entrepreneurship, 34(7), 895-904. https://doi.org/10.1177/0266242616649250

Gawel, A. (2012). The case study method in entrepreneurial and managerial education in a knowledge-based economy. In P. Ammerman (ed.), The case study method in business education [Metoda studium przypadku w edukacji biznesowej]. Poznań: Bogucki Wydawnictwo Naukowe, 25-38.

Häkkinen, P., Järvelä, S., Mäkitalo-Siegl, K., Ahonen, A., Näykki, P., \& Valtonen, T. (2017). Preparing teacher-students for twenty-first-century learning practices (PREP 21): A framework for enhancing collaborative problem-solving and strategic learning skills. Teachers and Teaching, 23(1), 25-41.

Hodzic, S. (2016). Increasing PhD students' employability by focusing on the academic entrepreneurship. The analysis of the entrepreneurial competences. Tuning Journal for Higher Education, 3(2), 347. https://doi.org/10.18543/tjhe-3(2)-2016pp347-387.

Ismail, V.Y., Zain, E., \& Zulihar (2015). The portrait of entrepreneurial competence on student entrepreneurs. Procedia - Social and Behavioral Sciences, 169, 178-188. https://doi.org/10.1016/j. sbspro.2015.01.300.

Karimi, S., Biemans, H.J.A., Lans, T., Chizari, M., \& Mulder, M. (2016). The impact of entrepreneurship education: A study of Iranian students' entrepreneurial intentions and opportunity identification. Journal of Small Business Management, 54(1), 187-209.

Kearney, P. (1999). Enterprising ways to teach \& learn: Book 1. Enterprise principles. Enterprise Design. Retrieved from: https://books.google.pl/books?id=PFelAAAACAAJ

Kickul, J., Gundry, L., Mitra, P., \& Berçot, L. (2018). Designing with purpose: Advocating innovation, impact, sustainability, and scale in social entrepreneurship education. Entrepreneurship Education and Pedagogy, 1(2), 205-221. https://doi.org/10.1177/2515127418772177

Küttim, M., Kallaste, M., Venesaar, U., \& Kiis, A. (2014). Entrepreneurship education at university level and students' entrepreneurial intentions. Procedia - Social and Behavioral Sciences, 110, 658-668. https://doi.org/10.1016/j.sbspro.2013.12.910

Laditka, S.B., \& Houck, M.M. (2006). Student-developed case studies: An experiential approach for teaching ethics in management. Journal of Business Ethics, 64(2), 157-167. https://doi. org/10.1007/s10551-005-0276-3.

Lahti, R.K. (1999). Identifying and integrating individual level and organizational level core competencies. Journal ofBusiness and Psychology, 14(1), 59-75. https://doi.org/10.1023/A:1022906400927.

Leon, R. (2016). The development of the future European knowledge workers. An academic perspective. Management Dynamics in the Knowledge Economy, 4, 339-356.

Leon, R.-D. (2017). Developing entrepreneurial skills. An educational and intercultural perspective. Journal of Entrepreneurship, Management and Innovation, 13(2017), 97-121. https://doi. org/10.7341/20171346 
Li, J., Wu, S., \& Wu, L. (2008). The impact of higher education on entrepreneurial intentions of university students in China. Journal of Small Business and Enterprise Development, 15(4), 752-774. https://doi.org/10.1108/14626000810917843

Lumpkin, G.T., Hills, G., \& Shrader, R. (2004). Opportunity recognition. In Entrepreneurship: The Way Ahead, 73-90. https://doi.org/10.4324/9780203356821.pt2

Lynch, M., Kamovich, U., Longva, K.K., \& Steinert, M. (2019). Combining technology and entrepreneurial education through design thinking: Students' reflections on the learning process. Technological Forecasting and Social Change, 119689. https://doi.org/10.1016/j.techfore.2019.06.015

Moberg, K. (2014). Assessing the impact of entrepreneurship education: From ABC to PhD. Frederiksberg: Copenhagen Business School (CBS).

Nabi, G., Liñán, F., Fayolle, A., Krueger, N., \& Walmsley, A. (2017). The impact of entrepreneurship education in higher education: A systematic review and research agenda. Academy of Management Learning \& Education, 16(2), 277-299. https://doi.org/10.5465/amle.2015.0026

OECD. (2015). The definition and selection of key competencies. Executive summary. Retrieved from: https://www.oecd.org/pisa/35070367.pdf

Oosterbeek, H., van Praag, M., \& IJsselstein, A. (2010). The impact of entrepreneurship education on entrepreneurship skills and motivation. European Economic Review, 54(3), 442-454. https:// doi.org/10.1016/j.euroecorev.2009.08.002

Pittaway, L., \& Cope, J. (2016). Entrepreneurship education. International Small Business Journal: Researching Entrepreneurship, 25(5), 479-510. https://doi.org/10.1177/0266242607080656

Rasmussen, E.A., \& Sørheim, R. (2006). Action-based entrepreneurship education. Technovation, 26(2), 185-194. https://doi.org/10.1016/j.technovation.2005.06.012

Ratten, V., \& Usmanij, P. (2020). Entrepreneurship education: Time for a change in research direction? The International Journal of Management Education, 100367. https://doi.org/10.1016/j. ijme.2020.100367

Ross, J.W., \& Wright, L. (2000). Participant-created case studies in professional training. Journal of Workplace Learning, 12(1), 23-28. https://doi.org/10.1108/13665620010309765

Wach, K. (2014). Edukacja dla przedsiębiorczości: pomiędzy przedsiębiorczą pedagogiką a edukacją ekonomiczną i biznesową. Horyzonty Wychowania, 13(18), 11-31.

\section{Copyright and License}

This article is published under the terms of the Creative Commons Attribution - NoDerivs (CC BY- ND 4.0) License http://creativecommons.org/licenses/by-nd/4.0/ 